\title{
Politik Pangan: Konstruksi Kebijakan Dalam Rangka Konsolidasi Ketanahan Ekonomi Indonesia (Tinjauan Sosio-Historis Ku1tura1 Ekonomi Islam)
}

\author{
Arin Setiyowati \\ Arin.st@fai.um-surabaya.ac.id \\ Universitas Muhammadiyah Surabaya
}

\begin{abstract}
Ghazan Khan (1295-1353 M) and Sultan alauddin Khidji (1296-1316 M), both of them are Islamic leader who succes in Persia and india. They can drive their state Islamic system throught equality distribution of wealth policy. Both of them have a similar power to change their not good economic system to excelent. Agricultural policy by Ghazan Khan and The price control system by Sultan Alauddin Khan. Therefore, they drive the welfare society. Indonesia, is agrarian country and economics condition still haven't stable yet, especially it shows from some crisis tragedies both food and economy in Indonesian history. Therefore, this literature study to be effort to give a problem solving for indonesian economics condition based historical perspective from the best leader from Mongol generation. Its according with Indonesians wisdom and be urgent agenda to reformula, because food distribution sector and political will of government is important factor in food political of a state.
\end{abstract}

Keywords: Ghazan Khan, Sultan Alauddin Khidji, Food and market policy, Souvereignty of Indonesians Economic. 
Arin Setiyowati_Politik Pangan: Konstruksi Kebijakan Dalam Rangka Konsolidasi Ketahanan Ekonomi Indonesia (Tinjauan Sosio-Historis Kultural Ekonomi Islam)

\section{A. Pendahuluan}

“...bahwa di dalam perut itu ada kelaparan yang mudah marah. Jika amarah dari perut itu meledak, negara ini sungguh berada dalam keadaan amat bahaya..." (Shindunata)

Lapar. Sesungguhnya adalah kata yang merujuk pada tidak adanya asupan makanan yang diterima oleh tubuh manusia. Kata lapar dapat ditafsirkan dalam dua hal, yaitu menahan diri agar tidak memasukkan makanan ke dalam tubuhnya untuk memenuhi target tertentu, misalnya target pemenuhan perintah agama atau juga alasan kesehatan. Misalnya untuk mengurangi obesitas atau sebagai syarat untuk menjalani pembedahan secara medis. Kasus lapar dalam dua yang dipaparkan adalah lapar karena kesenjangan pelaku. Makna lapar yang kedua, lebih merujuk pada ketidakmampuan seseorang untuk menyediakan bahan makanan apapun termasuk dengan kualitas rendah sekalipun sebagai asupan tubuhnya. ${ }^{1}$ Gizi buruk, kelaparan dan kemiskinan seumpama satu jiwa satu badan, yang tidak bisa dipisah satu sama lain. Ketiga hal tersebut sangat berkaitan erat. Begitupula Indonesia, kemiskinan yang terjadi di Indonesia banyak disebabkan oleh adanya kebijakan yang tidak berpihak kepada rakyat. Atau dengan kata lain kemiskinan di Indonesia adalah kemiskinan struktural. Rakyat Indonesia dimiskinkan oleh beragam kebijakan pemerintah dan negara, salah satunya pilihan kebijakan ekonomi terhadap lahirnya kebijakan Konglomerasi. Demikianjuga dengan struktur politik yang telah ada semakin memberikan suasana ketimpangan keberpihakan hanya tertuju pada sekelompok orang, terutama pemegang modal.

Hal ini terbukti diantaranya dalam hal pangan. Merupakan kebutuhan dasar manusia yang pemenuhannya tidak dapat ditunda-tunda, karena itu penyelesaian pangan lazimnya menempati perhatian khusus dalam pembangunan bangsa. Meskipun upaya menyelesaikan masalah pangan telah dilakukan sejak lama, khususnya Orde Baru, namun soal pangan tetap aktual karena pangan selalu mengikuti dinamika 
Arin Setiyowati_Politik Pangan: Konstruksi Kebijakan Dalam Rangka Konsolidasi Ketahanan Ekonomi Indonesia (Tinjauan Sosio-Historis Kultural Ekonomi Islam)

pembangunan. Dengan keberhasilan pembangunan ekonomi dan sosial yang telah kita capai selama ini masalah pangan tidaklah semakin ringan, namun sama rumitnya dengan kompleksitas masalah pembangunan itu sendiri.

Seperti yang kita ketahui, kebijakan berkenaan pangan di Indonesia hingga saat ini belum menjadi instrumen bagi perbaikan dan peningkatan kesejahteraan rakyat. Kebijakan yang hadir selalu asimetri dengan kondisi riil masyrakat. Kebijakan yang seharusnya menjadi sebuah 'pengaman' bagi masyarakat agar dapat membuka akses untuk melakukan perbaikan atas hidupnya, ternyata yang terjadi adalah sebaliknya. Rakyat semakin tidak memiliki ruang untuk melakukan perbaikan kualitas hidupnya karena produk kebijakan yang ada lebih banyak menjadi beban bagi masyarakat.

Hal ini tidak lepas dari doktrin pembangunan yang seringkali diartikan melulu pada pertumbuhan dan perubahan. Jadi, pembangunan pertanian yang berhasil dapat diartikan kalau terjadi pertumbuhan sektor pertanian yang tinggi dan sekaligus terjadi perubahan masyarakat tani dari yang kurang baik menjadi lebih baik. Walaupun kata "pertumbuhan" dan "perubahan" ini kelihatannya sederhana, namun materi yang terkandung di dalamnya banyak sekali. Hal ini disebabkan karena banyak variabel yang membentuk pertumbuhan sektor pertanian dan perubahan yang terjadi itu besar sekali.

Sektor pertanian di Indonesia dianggap penting, karena melihat peranannya terhadap penyediaan lapangan kerja, penyedia pangan, penyumbang devisa negara melalui ekspor dan sebagainya. Oleh karena itu wajar kalau biaya pembangunan untuk sektor pertanian ini selalu tiga besar diantara pembiayaan sektor-sektor yang lain. Ditambah lagi peran pertanian dalam perekonomian indonesia bisa dilipatgandakan, karena Indonesia mempunyai keunggulan komparatif di bidang pertanian :

1. Dibandingkan negara maju dengan musim dinginnya, Indonesia bisa menanam dan menghasilkan sepanjang tahun.

2. Indonesia terletak di garis katulistiwa dengan iklim kepulauan dan tidak seperti Hindia dengan iklim daratan luas dengan suhu di musim 
kemarau yang sangat panas. Tingginya suhu di Indonesia sepanjang tahun cocok untuk pertumbuhan maksimum.

3. Jumlah sinar radiasi matahari yang mendorong pertumbuhan, melebihi jumlah radiasi di negara maju.

4. Indonesia terletak di luar zona angin topan, yang sering merusak tanaman di Jepang, Taiwan, Filipina, dan negara-negara lain.

5. Di Indonesia terdapat jutaan orang yang menganggur atau setengah menganggur, karena tidak memiliki tanah walaupun tersedia jutaan tanah kosong.

Indonesia sebagai negara kepulauan dengan penduduk yang mencapai 237 juta jiwa mempunyai masalah tersendiri dalam hal pemenuhan keutuhan pangannya. Sebaran wilayah Indonesia yang menghadapi kendala alam, memerlukan perhatian tersendiri pula. Di samping itu dengan keragaman tingkat kemajuan sosial ekonomi masyarakat menambah rumitnya persoalan untuk merumuskan langkah yang tepat dalam mengupayakan ketersediaan pangan secara merata. Karena itu aspek distribusi juga menempati bagian yang penting dalam perumusan kebijaksanaan pangan.

Indonesia merupakan negeri kaya raya yang menempatkan penduduknya sebagian besar sebagai nelayan dan petani. Sayangnya, bagai panggang jauh dari api. Kebijakan pemerintah untuk kedua kelas sosial masyarakat tersebut ini nun jauh di awang. Kenaikan harga pupuk yang mencekik petani yang malah menjadikan keterbatasan hasil panen karena terganjal biaya, kebijakan impor beras yang digulirkan pemerintah pun kian meredupkan harapan sebagian petani, sebab tak lain kebijakan ini hanya menguntungkan pasar internasional dan piihak-pihak pejabat indonesia tertentu, namun tidak berpijak pada kebutuhan mendasar petani.

Indonesia yang dikenal sebagai negara agraris ternyata hingga saat ini politik pembangunan yang dijalankan semakin jauh meninggalkan konsep pembangunan yang berbasis agraris. Jika ditilik dari pola kebijakan yang dijalankan oleh pemerintah selama ini, kebijakan 
Arin Setiyowati_Politik Pangan: Konstruksi Kebijakan Dalam Rangka Konsolidasi Ketahanan Ekonomi Indonesia (Tinjauan Sosio-Historis Kultural Ekonomi Islam)

pembangunan pertanian lebih banyak dijadikan instrumen untuk mendukung kepentingan struktur perdagangan dunia tanpa memperdulikan proteksi bagi keluarga petani yang semakin hari semakin terdesak oleh beragam kebijakan pemerintah yang sama sekali tidak prorakyat terutama petani.Departemen pertanian maupun perdagangan seolah memiliki garis hasrat yang sama dalam kiblat kebijakan pertanian maupun produk pertanian yang mengutamakan pasar dunia, sehingga melupakan daya jangkau rakyat Indonesia terhadap ketentuan-ketentuan harga pokok produksi pertanian yang tak terjangkau oleh rakyat bahkan keluarga petani yang memproduksi hasil pertanian tak mampu membelinya.

Situasi ini diperparah dengan peran Bulog yang tiada lain sebagai perusahaan yang berorientasi keuntungan, supaya tidak dikritik oleh DPR maupun presiden sehingga yang menjadi tumbalnya adalah petani dengan harga beli hasil panen dengan harga yang murah. Hal ini semakin membuat rakyat berjuang sendiri dalam memperjuangkan perlindungan dan pemenuhan kebutuhan hidupnya, sementara negara hanya berkedok pada ketidakmampuan maupun keterbatasan teknisnya untuk memenuhi.

Esensi ketahanan pangan bukanlah semata kemampuan untuk mengakses pangan dalam mencukupi kebutuhan pangan rumah tangga seperti yang tertuang dalam PP No. 68 tahun 2002. Ketahanan pangan juga tidak hanya berarti melimpahnya ketersediaan pangan, melainkan lebih pada kemampuan masyarakat untuk memenuhi kebutuhan pangannya, baik dari sisi kuantitas maupun kualitas. Selain itu masyarakat juga mampu melakukan kontinuitas produksi kebutuhan kebutuhan pangannya secara mandiri.

Prestasi yangpernah diraih oleh Indonesia sekitar tahun 1984-an adalah swasembada pangan. Definisi swasembada di sini adalah suatu kondisi dimana kebutuhan dalam negeri terpenuhi oleh produksi dalam negeri sendiri. Implikasinya bahwa kondisi swasembada itu selalu akan terjadi, karena definisi yang demikian sama dengan pengertian keseimbangan pasar domestik dalam keadaan tidak ada perdagangan 
internasional. Sehingga konsepsi tersebut kurang didukung oleh logika ekonomi, lebih dari itu konsepsi tersebut tidak relevan dengan sasaran atau tujuan kebijaksanaan pangan, yang tidak saja memandang kecukupan pangan (dalam hal ini beras) pada tingkat makro, namun juga tingkat mikro, yakni pada tingkat individu konsumen.

Kalau kita simak rumusan tujuan kebijaksanaan pangan dari Repelita ke Repelita, maka kita akan menemukan adanya empat sasaran pokok dari kebijaksanaan pangan itu, yaitu :2

- Penyediaan pangan pada jumlah yang cukup

- Harga yang layak/ terjangkau oleh konsumen

- Harga yang layak/merangsang bagi produsen dan

- Perbaikan keadaan gizi rakyat

Dengan memperhatikan tujuan kebijaksanaan pangan di atas, maka jelas terlihat bahwa konsep swasembada pangan yang dianut Indonesia bukanlah konsep yang bebas nilai, artinya tidak identik dengan konsep keseimbangan pasar.

Dilihat dari segi manajemen pembangunan, keberhasilan yang dicapai Indonesia dalam memenuhi kebutuhan konsumsi beras dari produk dalam negerinya sendiri sekitar tahun 1984-an merupakan hasil dari serangkaian langkah-langkah kebijaksanaan yang diterapkan Pemerintah, baik berupa rangsangan harga seperti harga dasar, harga pupuk, obat-obatan pembunuh serangga dan suku bunga, maupun yang berupa rangsangan non-harga seperti pembangunan irigasi, penyuluhan, penataan pengelolaan manajemen produksi, lembaga pemasaran, lembaga keuangan di pedesaan dan sebagainya.

Dalam mempertahankan swasembada beras, yang sangat penting dan pertama harus dilakukan adalah menjaga keseimbangan antara unsur-unsur pendukung yang telah memungkinkan tercapainya swasembada tersebut. Selain mekanisme pasar yang semakin efisien, faktor lain yang penting untuk diperhatikan dalam mempertahankan swasembada beras adalah perbaikan pasca panen. Sehingga dalam

${ }^{2}$ Arifin, Bustanil, Pangan dalam Orde Baru, Jakarta : Koperasi Jasa Informasi (KOPINFO), Cet Kedua 1994, hal 244-245. 
menghadapi tuntutan pasar tersebut, dan mengingat bahwa petani-petani Indonesia banyak dihadapkan pada kendala strultural, maka sangat dibutuhkan peningkatan efektifitas dan efisiensi rekayasa kelembagaan, sosial dan teknologi yang selama ini telah terbukti mempunyai peran yang besar dalam memacu peningkatan produksi padi.

Romantisme sejarah akan kejayaan bangsa Indonesia dalam hal pangan bukan tidak mungkin bisa diusahakan kembali dalam masa depan Indonesia. Dengan belajar ulang terkait kiat-kiat sukses dari pengalaman sebelumnya dan meminimalisisr kesalahan kebijakan yang pernah diambil. Terlebih jika ada tambahan referensi dari eksternal bangsa sebagai pembanding dalam menyempurnakan gagasan terkait ketahanan dan kemandirian pangan di Indonesia.

Melalui paper ini penulis bermaksud memberikan sumbangsih gagasan terkait rekonstruksi kebijakan pangan dengan perspektif sejarah dua pemimpin Islam dari bangsa Mongol yang berkuasa di wilayah Persia dan India yang memiliki beberapa latar yang sama dengan kondisi keIndonesiaan. Sehingga mampu memberikan gagasan baru terkait kebijakan pangan dengan tanpa meninggalkan pengalaman jatuh bangunnya Indonesia dalam rentetan sejarah pangan.

\section{B. Pembahasan}

\section{Perspektif Sejarah}

\section{a. Ghazan Khan}

Ghazan lahir pada tanggal 4 Desember 1271 M di Abaskun dekat Bandar-e-Shah, sebelah Tenggara pantai Laut Kaspia. la menikah dengan Kokechi, seorang putri Mongol yang dikirim oleh Kubilai Khan. la merupakan salah satu satu tokoh penting dalam perjalanan sejarah Islam abad pertengahan (1250-1500 M). Masa kecil Ghazan dihabiskan bersama kakeknya Abaga (1256-1282) dan dididik untuk mempelajari agama Budha dari biksu dan juga memiliki pengetahuan yang luas, sehingga ia menguasai bidang-bidang ilmu yang lainnya, yang paling menonjol adalah pengetahuan Ghazan tentang pertanian dan memiliki bakat murni dalam pertanian, serta penyebaran jenis-jenis tanaman baru. 
Selain bisa berbahasa Mongolia, Ghazan juga dapat berbicara dalam berbagai bahasa yaitu Arab, Persia, Hindi, Kashmiri, Tibet, Cina, Prancis dan Latin.

Pada awal November 1295 M, Ghazan Khan masuk Islam (proses menjadi Muslimnya ada banyak versi) dan namanya menjadi Mahmud Ghazan Khan. Masih pada bulan yang sama setelah Ghazan masuk Islam, ia langsung menjalankan segala amalan yang diperintahkan dalam Islam, misal memberikan sedekah dan zakat kepada fakir miskin, dan berpuasa pada bulan Ramadhan. Ghazan resmi memerintah Dinasti llkhan pada tanggal 3 November $1295 \mathrm{M}$, dalam usia 24 tahun. la adalah penguasa ke VII yang paling berbakat dari para penguasa lainnya yang memerintah di Iran dari tahun 1256-1353 M. Rezim Ghazan menggunakan gelar Khan bukan Ilkhan dan menjadikan Islam sebagai agama resmi Negara.

Pada masa Ghazan Khan berkuasa, banyak masalah yang dihadapi oleh masyarakat, salah satunya masalah ekonomi, yang mana pada pemerintahan sebelumnya ekonomi tidak terstruktur dengan baik. Salah satu faktor penting yang mendukung lancarnya kebijakan ekonomi Ghazan adalah masyarakat, terutama dari golongan petani. Mengingat latar geografis daerahnya cocok untuk pertanian. Dengan kembalinya para petani untuk bertani, maka tanah Persia menjadi subur. Oleh karena itu pemasukan ke kas negara menjadi bertambah.

Mata pencahariaan paling utama penduduk Persia yaitu bertani, yang otomatis sebagai salah satu sumber pendapatan utama Negara. Setelah munculnya gagasan Mongol yang mana mereka menyatakan perang dan keunggulan seni militer dan sebagai gantinya mereka memberikan masyarakat stabilitas dan kedamaian, pertanian mengalami kemunduran. Kekuatan politik bangsa mongol dikembangkan dengan cara menyediakan padang rumput yang luas pada unit kesukuan yang membentuk pendukung militernya (Chapra, 2001: 172).

Pada masa Dinasti llkhan sebelumnya, keadaan di atas dipengaruhi dengan adanya pajak yang tinggi, sehingga para petani merasa dirugikan 
kemudian mereka membakar lahan dan berlindung dihutan. Melihat kondisi para petani, Ghazan yang mengerti baik sumber daya utama wilayahnya yaitu lahan pertanian yang sangat subur. Ghazan segera melakukan perbaikan dalam bidang pertanian. Agar masyarakat mau kembali bertani, maka Ghazan mengurangi pajak dari hasil pertanian seminimal mungkin. Kemudian dia menyediakan biji-bijian dan kawanan lembu, serta memperbaiki sistem irigasi. Kebijakan lainnya dalam bidang pertanian adalah menghidupkan kembali tanah mati. Tanah mati tersebut dibagi menjadi tiga.

- Pertama, tanah yang memiliki persediaan air, yang tidak memerlukan banyak pekerja. Pada tahun pertama tanah tersebut tidak dikenakan pajak, tahun kedua 1/3 pajak diwan harus dibayar, dan tahun ketiga 3/4 pajak diwan harus dibayar.

- Kedua, tanah yang membutuhkan air dan pekerja dalam jumlah yang tidak banyak. Tidak ada yang dibayar pada tahun pertama. Tahun kedua, pajak diwan dibayar 1/3 dan tahun ketiga 2/3.

- Ketiga, tanah yang membutuhkan perbaikan trowongan air bawah tanahnya. Tidak ada yang dibayar pada tahun pertama dan tahun kedua 1/3 pajak diwan yang harsu dibayar, serta tahun ketiga harus dibayar 1/2. Akan tetapi, tanah mati tersebut harus didaftarkan dan diperbaharui setiap tahun oleh Diwan-e Khatsha, guna untuk mengawasi tanah tersebut. (Lambton, 1969: 91)

Adapun kebijakan fiskal Ghazan Khan yang diberlakukan dalam rangka menggawangi kebijakan pertaniannya adalah sebagai berikut :

Ghazan melarang pemungutan pajak oleh gubernur, karena sering melakukan kecurangan. Ghazan memilih orang-orang kaya untuk menjadi kolektor pajak (memungut pajak). Menurutnya, orang kaya itu sudah cukup puas dengan apa yang telah mereka miliki, sehingga tidak akan melakukan tindakan korupsi.

Ghazan mengirim beberapa bitikchi (sekretaris Negara) ke setiap propinsi guna mencatat harta kepemilikan penduduk. Para sekretaris 
Negara tersebut harus menyerahkan hasil pendataannya kepada diwan, kemudian ghazan juga mengangkat sekretaris Negara dari setiap propinsi untuk menulis draf di pemerintahan pusat pada awal tahun sesuai dengan pendataan terhadap penduduk. Selanjutnya Ghazan mengangkat Sahib-e-jam (kolektor pajak) disetiap propinsi. Di setiap kota didirikan posko sebagai tempat pembayaran pajak, sejak tanggal ditetapkannya pembayaran pajak sampai tahap jatuh tempo. Pembayaran pajak dilakukan dengan 2 angsuran, dengan biaya tambahan 10,5 \%. Beserta iuran kas Negara. Jika mereka telat membayar pajak, makan akan dikenakan denda sebesar $1 \%$ dari total tagihan pajak. Pajak merupakan sebuah instrument utama dalam kebijakan ekonomi dan bertujuan untuk menjamin pertumbuhan dan stabilitas perekonomian Negara. Berdasarkan pemikiran diatas, Ghazan kemudian menetapkan pajak kepada masyarakat sesuai kesepakatan yang telah dibentuk oleh Ghazan dengan para perdana menteri (Rosidah, 2012: 51-52)

a. Pajak Penduduk : Pertama, pajak keluarga untuk orang islam yang disebut zakat.Kedua, pajak keluarga non-Islam yang disebut Jizyah yaitu sebagai jaminan keamanan diri.

b. Pajak Tanah : Pembayaran pajak pendapatan pertanian kepada penduduk lokal, seperti pedagang, pemilik tanah, anggota birokrasi dan para amir. Sistem pembayaran dapat dilakukan dengan dua angsuran, yaitu pada musim panas (garmsir) dan musim dingin (nardsir). Pada musim dingin dan musim panas jatah gandung untuk Negara harus diserahkan dalam jangka waktu dua puluh hari.Apabila seseorang ingin menggarap sebuah kebun yang sudah tidak ditanami lagi, maka ia bebas untuk mendapat bagian $1 / 2$ dari tarif pajak diwan dan 1/10 nya dibayarkan untuk pajak. Kemudian apabila pada propinsi tersebut tidak ada kharaj, maka 1/10 itu menjadi hak pemilik tanah. Pada masa Ghazan, Dinasti Ilkhan merupakan satu-satunya Negara dalam sejarah Bangsa Mongol 
yang mampu mengekspor beras ke mancanegara (Lambton, 1988: 179).

c. Pajak Hewan Ternak : Setelah Ghazan berkuasa, pajak qubchur(hewan ternak) ditarik secara teratur yaitu dua kali angsuran pada musim semi dan musim gugur, kemudian pajak ini dibebankan kepada penduduk lokal dan nomaden. Pajak tersebut harus dibayarkan dalam jangka waktu dua puluh hari, sedangkan penduduk nomaden adalah satu kali angsuran yaitu pada musim semi dan pajak tersebut juga dibayarkan dalam jangka waktu dua puluh hari (Lambton, 1988: 215).

d. Pajak Bea Cukai Barang dan Jasa : Pajak yang ditarik dari aktifitas kota, seperti perdagangan, pajak toko-toko dan pemandian umum.

Adapun kebijakan moneter yang diambil oleh Ghazan Khan sebagai berikut ; Pendirian Lembaga Keuangan (Ghazan membangun tenda-tenda untuk menyimpan uang Negara yang dijaga dengan ketat dan dia juga membuat "Buku Penjaga" yaitu buku khusus tentang pencatatan uang keperluan Negara. Ghazan juga memilah-milah harta benda yang telah diterimanya oleh propinsi-propinsi lain (Abdul Karim, 2006: 111)).

Sementara kebijakan moneter sebagai berikut ;

a. Pendapatan Negara ; Saat Ghazan Khan berkuasa pendapatan utama Negara berasal dari pajak, terutama pajak pertanian dan dari pajak hewan (qubchur) ternak dan pajak bea cukai barang dan jasa (tamgha), zakat, jizyah, tanah Negara, iqta dan wakaf (Lambton, 1988: 115-129)

b. Pengeluaran Negara ; sebagian terserap oleh kebutuhan pembangunan infrastruktur, ia membangun pusat-pusat perdagangan misalnya, Tabriz selain menjadi ibu kota, tapi juga menjadi pusat perdagangan antara Timur dan Barat. Berikutnya adalah untuk pembangunan fisik, Ghazan membangun musolium, rumah-rumah supaya kota tersebut ramai penduduk, pembagunan jembatan, air mancur, biara atau khanqah (pondok santri tradisional), perguruan tinggi untuk madzhab Hanfi dan Syafi'l, perumahan untuk para sayyid, 
rumah sakit, dan gedung-gedung umum lainnya.Pengeluaran Negara yang lainnya adalah pembelian senjata untuk kebutuhan militer. Kemudian pembayaran gaji untuk para tentara, menteri, gubernur dan para pejabat lainnya, serta untuk sumbangan.

\section{b. Sultan Alauddin Khadji}

Sultan Alauddin Khalji (1296-1316), seorang pemimpin India abad XIII dari kesultanan Khalji yang menguasai dan mengendalikan secara luas daerah-daerah Pusat dan Selatan India. ${ }^{3}$ Dia adalah putra Yaghrish Khan, sedagkan Yaghrish Khan merupakan saudara dari Jalaluddin Khalji (Jalaluddin Feroze) seorang sultan pertama di dalam kesultanan Khalji. Alauddin Khalji memiliki saudara kandung Ulugh Khan, yang mana kedua bersaudara ini kemudian dijadikan menantu oleh Jalauddin Khalji sekaligus diberikan posisi penting dalam pemerintahan. ${ }^{4}$ Menurut catatan Nizamuddin penulis Tabqat-e-Akbari, Jalaluddin Khalji merupakan cucu dari Khaalij Khan, sedangkan Khalij Khan adalah salah satu menantu dari Chengis Khan. Khalij Khan menetap di negeri dataran tinggi Ghur dan Gurjistan setelah Khawarizm shah ${ }^{5}$ ditaklukkan oleh Cengis Khan. ${ }^{6}$

Pemerintahannya hanya berjalan dua puluh tahun, namun ia memiliki ambisi besar untuk menjadi penguasa seperti Alexander agung $\mathrm{II}^{7}$ dan menginginkan menjadi nabi, dengan alasan bahwa Nabi memiliki empat sahabat (al-Khulafa al-Rasydin), ia juga memiliki empat sahabat, yaitu Ulugh Khan, Ja'far Khan, Nusrat Khan, dan Alap Khan. Hal-hal tersebut ketika dimintai pendapat dari Alaul Mulk $^{8}$, orang kedua di dalam Kesultanan. Alaul Mulk memberi masukan kepada sultan, sebaiknya meninggalkan ambisi untuk menguasai dunia, lebih baik mencurahkan

\footnotetext{
${ }^{3}$ Thohir, Ajid, Perkembangan Peradaban di Kawasan Dunia Islam, (Jakarta : Raja Grafindo Persada, 2004), hal 200.

${ }^{4}$ Elliot, The History.,hal 137

${ }^{5}$ Kepemimpinan Khawarizm Shah dipegang oleh putranya Jalaluddin Ibn Khawarizm Shah, ia berhasil dikalahkan oleh Cengis Khan sehingga pasukan Cengis Khan berhasil menguasai Ghaznah. Sedangkan Pasukan Jalaluddin Ibn Khawarizm Shah melarikan diri dan mengarungi laut menuju India. Peristiwa ini terjadi pada tahun 620 H/ 1223 M : M. Sayyid alWakil, Wajah Dunia Islam., hal 250.

${ }^{6}$ Niazi, The Life., hal 15

${ }^{7}$ H. G. Keene, History of India, (Edinburgh : John Grant, 1906), I : 56.

${ }^{8}$ juga merupakan paman dari ahli sejarah terkemuka Ziauddin Barani 
pemikirannya untuk membangun India. ${ }^{9}$ Jika Sultan masih berkehendak untuk menjadi Nabi, rakyat dan para ulama akan meninggalkan Sultan. ${ }^{10}$ Kemudian Alauddin mulai berpikir dan berupaya untuk Negaranya. Untuk mewujudkan cita-citanya tersebut ia berpikir keras membangun pasukan yang hebat, padahal di awal pemerintahannya kondisi negara dipenuhi dengan budaya korupsi, serta menghamburkan uang untuk pesta minuman keras dan wanita di antara para pejabatnya. ${ }^{11}$ Kondisi ekonomi di awal pemerintahan Sultan Alauddin menghadapi masa kritis karena harga barang pokok sangat tinggi dan langka disebabkan aksi penimbunan oleh para pedagang, perampokan merajalela sehinga perekonomian menjadi tidak berkembang, administrasi negara yang mengatur keadaan pasar tidak berjalan efektif, dan petugas negara di daerah yang bertugas dalam masalah pertanian cenderung mengeksploitasi petani secara tidak jujur. ${ }^{12}$ Kondisi keamanan dalam negeri juga dipenuhi dengan pemberontakan, dan dari luar negeri ada serangan bangsa Mongol yang tidak diketahui kapan dan seberapa besar kekuatannya. Namun keadaan ini dapat diselesaikan dengan sukses, kunci dari keberhasilan Sultan Alauddin Khalji adalah melakukan perbaikan ekonomi yang dikenal dengan sistem pengendalian harga (Price Control System) dan banyak sejarahwan menilai kebijakan ekonominya ini berhasil. ${ }^{13}$

Yang menjadi alasan pokok dari kebijakan Sultan Alauddin dalam pengendalian harga ini adalah karena kondisi awal pemerintahannya yang mana rakyat kelaparan karena pasokan makanan langka dan harga melambung tinggi, akibat olah dari pedagang 'nakal' salah satunya yang melakukan penimbunan barang selain faktor terputusnya jalur perdagangan. Bersamaan dengan hal tersebut, khas negara kosong,

\footnotetext{
${ }^{9}$ Sebab, alexander Agung memiliki seorang wazir yang pandai dalam bidang pemerintahan dan disiplin ilmu pengetahuan yang lain, yaitu Aristoteles, sedangkan Sultan tidak memiliki penasehat sepandai itu. Sementara itu, jabatan Kenabian tidak dimiliki oleh semua orang, tidak semua penguasa menjadi nabi, namun ada nabi yang menjadi penguasa. Jabatan kenabian merupakan hak mutlak Tuhan.

${ }^{10}$ Karim, M. Abdul, Sejarah Pemikiran dan Peradaban Islam, (Yogyakarta : Pustaka Book Publisher, 2012 ), hal 266.

${ }^{11}$ Niazi, The Life.., hal 94.

12 Ibid, hal 45-70.

${ }^{13}$ K. Ali, History of India Pakistan and Bangladesh, (Dacca : Ali Publications, 1980), hal 140. 
sehingga perlu ada kebijakan yang terintegrasi dalam menyelesaikan persoalan ekonomi ini.

Adapun kebijakan-kebijakan dalam Mengendalikan harga yang diambil Sultan Alauddin Khalji sebagai berikut :

1. Menetapkan harga kebutuhan pokok (yakni gandum, jamawut (barley), dhan (gabah), ghur (gula dari pohon kurma), mentega, garam, gula merah, minyak sesamum, dsb) dan kebutuhan mendesak lainnya dalam harga yang sangat murah, termasuk untuk harga seluruh barang yang digunakan untuk memenuhi kebutuhan hidup (misal sayuran, buah-buahan, peci/kopiah, sepatu, senjata, jarum, kuda yang paling bagus, sapi perah, kerbau perah, dsb). Yang menarik mengapa jarum atau alat tenun, peci, dan sepatu juga dipatok harga? ${ }^{14}$ Sehingga dengan pematokan harga tersebut tidak membuat biaya produksi meningkat yang berakibat matinya usaha utama masyarakat yang lebih jauh berdampak pada bertambahnya angkan pengangguran dan kemiskinan.

Daftar Barang dan Harga dalam Kebijakan Penetapan Harga

\begin{tabular}{|l|l|l|}
\hline Nama Barang & Satuan & Harga \\
\hline Gandum (wheat) & $\begin{array}{l}1 \text { maund }( \pm 40 \\
\mathrm{kg})\end{array}$ & $7 \frac{1}{2}$ jital \\
\hline Jamawut (barley) & $\begin{array}{l}1 \text { maund }( \pm 40 \\
\mathrm{kg})\end{array}$ & 4 jital \\
\hline Gram & $\begin{array}{l}1 \text { maund }( \pm 40 \\
\mathrm{kg})\end{array}$ & 5 jital \\
\hline Gabah (dhan) & $\begin{array}{l}1 \text { maund }( \pm 40 \\
\mathrm{kg})\end{array}$ & 5 jital \\
\hline Bubur (mash) & $\begin{array}{l}1 \text { maund }( \pm 40 \\
\mathrm{kg})\end{array}$ & 5 jital \\
\hline Moth & $\begin{array}{l}1 \text { maund }( \pm 40 \\
\mathrm{kg})\end{array}$ & 3 jital \\
\hline
\end{tabular}

${ }^{14}$ Karena dimungkinkan didasarkan bahwa di India terutama di Bangla dan Gujarat terkenal sebagai pengekspor barangbarang tekstil: M Abdul Karim, Sejarah Islam di India, (Yogyakarta : Bunga Reflesia Production, 2003), hal 5. 
Arin Setiyowati_Politik Pangan: Konstruksi Kebijakan Dalam Rangka Konsolidasi Ketahanan Ekonomi Indonesia (Tinjauan Sosio-Historis Kultural Ekonomi Islam)

\begin{tabular}{|l|l|l|}
\hline Gula & 1 seer $( \pm 1 \mathrm{~kg})$ & $1_{2}^{1} \mathrm{jital}$ \\
\hline Gula dari pohon kurma (Ghur) & 1 seer $( \pm 1 \mathrm{~kg})$ & $\begin{array}{r}1 \\
\mathrm{jital}\end{array}$ \\
\hline Mentega & $2{ }_{2}^{1}$ seer & $1 \mathrm{jital}$ \\
\hline Minyak sesamum & 1 seer & 1 jital \\
\hline Nakhud & 1 maund & 5 jital \\
\hline Garam (salt) & $2 \frac{1}{2}$ maund & 5 jital \\
\hline Kuda (kualitas terbaik) & 1 ekor & $\begin{array}{l}120 \text { tanka }(1 \text { tanka } \\
=64 \text { jital }\end{array}$ \\
\hline Sapi Perah (milch cow) & 1 ekor & 4 tanka \\
\hline Kerbau Perah (milch buffalo) & 1 ekor & 6 tanka \\
\hline
\end{tabular}

2. Menunjuk Malik Kabul Ulugh Khan, seorang praktisi dan bijak untuk memantau pasar. Ulugh khan melaksanakan tugasnya dibantu oleh Intelejen yang memberikan informasi semua praktek yang dilakukan setiap pedagang. ${ }^{15}$ Pasar yang ada ketika zaman Sultan alauddin diserahkan pengelolannya kepada dua pejabat yaitu Diwan-e Riyasat (yang mengawasi pasar yang menjual kebutuhan sandang (pakaian) dan pasar secara umum) dan Shahana-e-Mandi (yang mengawasi pasar khusus yang menjual bahan makanan). Malik Kabul Ulugh Khan adalah pejabat pertama sebagai Shahana-e-Mandi dan dibantu oleh banyak staf, sedangkan Yakub adalah pejabat pertama Diwan-e Riyasat. Selain mereka Sultan juga menunjuk sejumlah mata-mata yang selalu memberikan laporan kepada Sultan tentang kondisi pasar. $^{16}$

3. Membangun lumbung gandum untuk menampung bahan kebutuhan pokok terutama gandum. Sultan Alauddin berusaha meghilangkan kelangkaan barang dan mengendalikan kenaikan harga gandum (bahan makanan pokok). Sejarahwan Barani mengatakan bahwa ada dua hukum yang berlaku saat itu yaitu gandum tidak boleh dibiarkan 
langka (kekurangan) dan tidak boleh muncul harga di atas harga yang ditetapkan oleh Sultan. ${ }^{17}$

4. Membuat petugas pengangkut yang ditempatkan di seluruh wilayah kekuasaannya di bawah perintah pengendali pasar ${ }^{18}$ yaitu Diwan-eRiyasat dan Shahana-e-Mandi. Tugasnya mengangkut gandum dari satu wilayah negara ke wilayah negara yang lain secara kolektif atau ke pasar yang disebut Sara-e $A d l,{ }^{19}$ nama mereka pun tertulis dalam sebuah buku yang disebut Daftar dan ditempatkan dalam gudanggudang di tepi sungai Jamuna. Apabila mereka melakukan kelalaian maka akan dihukum secara kolektif juga. ${ }^{20}$

5. Melarang tindakan penimbunan. Berbagai tidakan yang biasa dilakukan para pedagang seperti penimbunan gandum dilarang dan pelakunya akan mendapat hukuman. Yang mana pedagang tidak diperbolehkan menyimpan gandum lebih dari 1 maund dan menjualnya di atas harga yang sudah ditetapkan. ${ }^{21}$ Serta seluruh pedagang harus mendaftar diri di dalam daftar dan diserahkan pengawasannya kepada pejabat Shahana-e-Mandi. ${ }^{22}$ Selain pedagang, penduduk pun tidak boleh menyimpan cadangan gandum melebihi dari yang mereka butuhkan dan tidak diperbolehkan pedagang yang menjual kepada pembeli lebih dari yang mereka butuhkan. Selain itu barang-barang import juga diawasi, sehingga pedagang tidak menjual barang tersebut dalam jumlah besar dengan tetap mengikuti harga yang telah ditetapkan pemerintah. Beberapa jenis barang tertentu disalurkan kepada mereka atas izin dari lembaga pengendali pasar. Selain itu Sultan Alauddin juga melarang praktek buruk para (broker) perantara di pasar, yang mana biasanya mengambil atau meminta uang dari kedua pihak (pembeli dan pedagang), karena akibat ulah mereka bisa menyebabkan harga barang di pasar melambung tinggi, padahal harga

\footnotetext{
${ }^{17}$ Gudang Gandum (bulog) dibangun di Delhi, gandum yang dihasilkan di wilayah New city dan Jhain diangkut ke Delhi menggunakan angkutan milik pemerintah hingga terisi penuh. Sultan membangun banyak gudang di Delhi, dan ia tidak membiarkan satu gudang gandum yang kosong dari gandum saat musim panen : Elliot, The History.,hal 193.

${ }^{18}$ Ibid, hal 193.

${ }^{19}$ Ali, K., History.,hal 82.

${ }^{20}$ Niazi, The Life.,hal 61.

${ }^{21}$ Elliot, The History., hal 194

${ }^{22}$ Ali, K., History.,hal 82. 
yang diinginkan Sultan adalah harga murah untuk warganya. Kemudian praktek buruk pedagang yang dilarang yakni mengurangi timbangan, walaupun harga yang diterapkan sesuai ketetapan Sultan. Praktek ini sering menimpa pembeli yang tidak paham atau anak kecil, dan apabila ketahuan ada pedagang yang melakukan hal tersebut maka akan diberi hukuman seperti pukulan atau memotong sebagian kulit pedagang setara dengan timbangan yang mereka kurangi. ${ }^{23}$ Awalnya Sultan ingin menghindari memberikan hukuman berat ini, namun penduduk sangat susah menghilangkan kebiasaan mengurangi timbangan tersebut, sehingga dengan tujuan mencegah diharapkan kerusakan tersebut dapat dihilangkan mulai dari pedagang secara pribadi dengan hukuman tadi.

6. Memberikan penegasan kepada pejabat pemungut pajak dan asistennya di wilayah bagian untuk menjamin peningkatan jumlah gandum yang akan diangkut ke lumbung gandum milik negara dengan harga yang telah ditetapkan oleh pemerintah, selain itu juga instruksi kepada seluruh pejabat terkait untuk memungut pajak secara rutin sebelum para pengelola tanah membawa hasil panen gandum itu ke dalam rumah mereka. Cara ini membuat pengelola tanah terpaksa menjual dengan harga yang rendah kepada petugas pengangkut gandum. Para penduduk juga diperbolehkan membawa sendiri gandum mereka ke pasar untuk dijual tetapi dengan syarat menjualnya dengan harga yang telah diatur. ${ }^{24}$

7. Membuat sistem pelaporan harian Kepada Sultan, yang mana berisi keadaan harga pasar dan transaksi yang dilakukan pelaku pasar. Sistem pelaporan ini dibuat dari tiga sumber yang berbeda yaitu laporan dari pengawas pusat berisi tingkat harga dan praktek transaksi pada harga tersebut, laporan dari petugas lapangan berisi pengumuman, dan laporan dari mata-mata berisi laporan. Termasuk di dalamnya informasi tentang barang yang masuk dan keluar pasar secara umum juga dilaporkan kepada Sultan. Sistem pelaporan ini 
tidak memberikan peluang adanya penyimpangan informasi, apabila ada perbedaan laporan yang diterima Sultan maka pengawas pusat akan menerima hukuman. ${ }^{25}$

Dari Alur pemerintahan Sultan Alauddin Khalji, secara formulasi ekonominya sebagai berikut :

Dalam kondisi negara yang perekonomiannya kalang kabut, yakni kas negara kosong, perang sehingga jalannya pemerintahan tidak efektif dan efisien, sehingga menimbulkan ketiadaan keseganan dari rakyatnya, menimbulkan kejahatan baik di lingkungan sosial maupun pasar seperti monopoli harga di pasar, penimbunan barang-barang pokok atau kebutuhan sehari-hari dan praktek-praktek ketidakjujuran lainnya. Sehingga berpengaruh juga pada perubahan jumlah produksi, permintaan, ini berakibat pada jumlah uang yang beredar, tingkat harga, bahkan tingkat upah, sehingga berimbas pada kesempatan kerja, pendapatan masyarakat, sirkulasi perdagangan dalam dan luar negeri, ini faktor-faktor eksogen dalam ekonomi yang mempengaruhi pendapatan nasional maupun kondisi pasar.

Dari permasalahan monopoli, kita tahu sendiri bahwa efek dari adanya monopoli yaitu ${ }^{26}$ : Pertama, hilang atau berkurangnya tingkat kesejahteraan konsumen (volume produksi lebih kecil daripada volume output optimum, menimbulkan inefisiensi sehingga kesejahteraan konsumen berkurang). Kedua, menimbulkan eksploitasi terhadap konsumen dan pemilik faktor produksi. Ketiga, menimbulkan kondisi makroekonomi negara memburuk, karena output riil industri lebih kecil daripada kemampuan sebenarnya karena motif tertentu. Sehingga ketika kondisi negara sudah parah seperti itu, sudah dipastikan inflasi menjadi keniscayaan yang dianggap sebagai penyakit ekonomi.

Oleh sebab itu, tepat ketika Sultan atas nama negara (atas nama pemerintah) mengambil alih kendali perekonomian dengan menetapkan seluruh harga bahan pokok dan bahan utama produksi dengan harga

\footnotetext{
${ }^{25}$ Ibid, hal 19.

${ }^{26}$ Al Arif M Nur Rianto dkk, Teori Mikroekonomi : Suatu perbandingan Ekonomi Islam dan Ekonomi Konvensional, (Jakarta : Kencana, 2010), hal 240. 
Arin Setiyowati_Politik Pangan: Konstruksi Kebijakan Dalam Rangka Konsolidasi Ketahanan Ekonomi Indonesia (Tinjauan Sosio-Historis Kultural Ekonomi Islam)

sangat murah sehingga terjangkau oleh rakyat yang miskin (yang mulanya kelaparan karena tidak mampu menjangkau harga gandum dll).

\section{c. Alur Kejayaan dan Kemunduran Pangan di Indonesia}

Perjalanan sektor pertanian di Indonesia semenjak 1967 sampai sekarang secara umum mengalami lima fase : fase konsolidasi, fase tumbuh tinggi, fase dekonstruksi, fase krisis, fase transisi dan desentralisasi (Arifin, 2004) Kinerja ekonomi pertanian selama kurun waktu tersebut menunjukkan pertumbuhan tanaman pangan yang terus menurun setelah tahun 1986. Ini berarti ketersediaan pangan secara otomatis juga mengalami tren menurun. Berikut alurnya ;

a. Pada fase konsolidasi 1967-1978, tanaman pangan tumbuh dengan $3,58 \%$. Tiga kebijakan yang diterapkan pemerintah pada fase ini dalam membangun pertanian yaitu melalui intensifikasi (penggunaan teknologi biologi dan kimia (pupu, benih unggul, pestisida, dan hibrisida) serta teknologi mekanis (traktorisasi dan kombinasi manajemen air irigasi serta drainase)), ekstensifikasi (perluasan areal dengan mengkonversi hutan yang tidak produktif) dan diversifikasi (penganekaragaman usaha pertanian untuk menambah pendapatan rumah tangga petani).

Pada saat yang bersamaan Pemerintah juga melakukan kebijakan ;

- membangun sarana irigasi, jalan dan industri pendukung

- melakukan pembenahan institusi ekonomi seperti konsolidasi kelompok tani hamparan, KUD dan koperasi pertanian lainnya, sistem penyuluhan.

- Melakukan terobosan skema pendanaan, memberikan kredit pertanian (walau bersubsidi), serta keterjangkauan akses finansial sampai ke tingkat pelosok pedesaan.

b. Pada fase tumbuh tinggi tahun 1978-1986, tanaman pangan tumbuh dengan 4,95\%, dimana pada masa ini penerapan revolusi hijau membawa Indonesia kepada pencapaian swasembada pangan pada tahun 1984. Kontribusi riset atau ilmu pengetahuan dan teknologi dalam sektor pertanian menjadikan kinerja produksi pertanian 
meningkat. Revolusi teknologi menjadi salah satu indikasi tingkat pemerataan di tingkat pedesaan, daerah produksi padi identik dengan kesejahteraan pedesaan. Kinerja yang baik dari institusi ekonomi di tingkat desa, kelompok tani, koperasi pedesaan, sistem penyuluhan, dukungan skema pendanaan dan sistem perbankan, kesemuanya menghasilkan kinerja yang baik pada produksi pertanian. Manajemen pemerintahan Seharto dengan sistem linier dan komando sangat efektif untuk menjalankan administrasi pemerintah sampai ke tingkat pedesaan. Sebagai contoh, kebijakan harga dasar gabah dan manajemen operasi pasar untuk menjaga stabilitas harga pangan, berjalan efektif karena persyaratan detail implementasi kebijakan sudah dipersiapkan, mulai pegudangan, armada transportasi, dukungan kredit perbankan sampai pada waktu pengumuman harga dasar baru. Antisipasi harga beras di pasar dunia juga diperhatikan secara seksama.

c. Pada fase dekonstruksi tahun 1986-1997, tanaman pangan hanya tumbuh 1,90 \%. Fase ini dinamakan dekonstruksi karena sektor pertanian mengalami fase pengacuhan (ignorance) oleh para perumus kebijakan dan bahkan para ekonom sendiri. Pencapaian swasembada pangan menimbulkan persepsi bahwa pembangunan pertanian akan bergulir dengan sendirinya, sehingga melupakan prasyarat keberpihakan serta kerja keras pada periode sebelumnya. Indikasi fase buruk ini sebenarnya muncul pada tahun 1990-an ketika kebijakan pembangunan ekonomi mengarah ke strategi industrialisasi, dimana berbagai komponen proteksi diberikan ke sektor industri, sehingga pertumbuhan sektor industri meningkat pesat, sampai menimbulkan anggapan bahwa proses transformasi struktur ekonomi (dari negara agraris ke negara industri) telah berhasil. Upaya proteksi ke sektor industri dilakukan secara sistematis sehingga melumpuhkan basis pertanian di tingkat petani pedesaan, yang pada akhirnya menimbulkan ketidakmerataan pembangunan antara pedesaan dan perkotaan, bahkan juga antara pulau Jawa dan luar Jawa. 
d. Pada fase krisis ekonomi pada 1997-2001, tanaman pangan hanya tumbuh $1,62 \%$. Pada masa ini yang berawal tahun 1997, terjadi krisis ekonomi yang dipicu oleh krisis nilai tukar dan perbankan, yang kemudian berdampak pada semua sendi perekonomian (inflasi meningkat, pengangguran bertambah sebagai akibat dari pemutusan hubungan kerja), yang selanjutnya menjalar kepada sistem politik. Sektor pertanian harus menanggung dampak krisis ekonomi melalui keharusan menyerap limpahan tenaga kerja sektor informal perkotaan. Dampaknya adalah sektor pertanian termasuk petani, terus terpojok dan terpinggirkan misalnya dalam hal fasilitas.

e. Pada fase 2001 sampai sekarang merupakan fase transisi politik dan periode desentralisasi. Pembangunan pertanian perlu diterjemahkan menjadi peningkatan basis kemandirian daerah yang secara teoritis dan empiris mampu mengalirkan dan bahkan menciptakan dampak ganda aktivitas lain di daerah. Otonomi daerah perlu diterjemahkan sebagai suatu kewenangan daerah untuk lebih leluasa melakukan kombinasi strategi kompetitif yang ada di suatu daerah otonom, khususnya dalam kerangka pembangunan pertanian dan sektor ekonomi lain pada umumnya.

\section{d. Kondisi Kekinian ; Perlakuan Terhadap Subyek Pertanian}

Dewasa ini, petani seolah sebagai kaum miskin yang terlemahkan oleh sistem tanpa ada pembelaan dari negara (pemerintah). Mulai dari tanah yang hari ini gencar-gencarnya pembangunan perumahan, perhotelan, maupun perusahaan. Belum lagi permasalahan tanah yang terkadang tidak bersahabat dengan petani akibat musim maupun efek hama dan obat tanah yang berlebihan. Sementara petani yang sedari awal sudah tercekik karena kebijakan harga pupuk yang mahal, belum lagi adanya musim panca roba yang tidak menentu, bibit tanaman yang mahal, obat pembasmi hama maupun gulma yang melangit harganya. Alih-alih meringankan beban dan menunjang hasil tanam 
mereka, kebijakan pemerintah justru menyebabkan keterbatasan hasil panen karena terganjal biaya.

Kebijakan impor beras yang digulirkan pemerintah pun kian meredupkan harapan sebagian besar masyarakat petani, sebab kebijakan ini tak lain hanya menguntungkan pasar internasional, tapi tidak berpijak pada kebutuhan mendasar para petani. Karena jelas, ketika produk-produk pertanian maupun agrikulturnya dalam negeri dihadapkan dengan produk impor yang harganya lebih murah, sementara kualitasnya ada yang setara maupun di bawah produk dalam negeri. Hal tersebut memaksa harga produk dalam negeri terpaksa banting harga, dan berbuah tidak ada penghargaan atas upaya para petani dalam menanam maupun merawat tanaman pangan kita. Dari rentetan permasalahan inilah yang menjadikan petani pesimis dalam meneruskan pekerjaannya sebagai petani, sehingga banyak yang beralih profesi dan menjual tanahnya kepada para pemilik modal yang ingin mengubah lahan persawahan menjadi lahan perkantoran maupun perumahan.

Dan lebih parahnya lagi ketika petani ingin menjual hasil pertaniannya harus terganjal dengan adanya para tengkulak yang memberikan harga serendah mungkin dan tidak sebanding dengan modal awal petani ketika menggarap sawahnya. Maka aliran trouble berikutnya saat hasil panen dijual hanya laku di bawah modal awal yang dikeluarkan oleh petani saat masa produksi atau menggarap sawah sampai masa panen, belum lagi tenaga yang dikeluarkan dalam merawat tanaman sawahnya. Sehingga tidak heran ketika di desadesa, yang menjadi langganan warga kurang mampu adalah mereka yang berprofesi petani, baik petani yang memiliki lahan tanah sendiri maupun petani tanpa lahan (buruh tani). Efek nyatanya mereka tidak mampu memenuhi kebutuhan (seperti makanan) dan pendidikan yang layak untuk anak-anaknya, sehingga mereka menjadi miskin dan semakin miskin karena tidak ada peningkatan taraf kehidupan, tiada lain efek dari jauh dari pendidikan. 
Inilah rangkaian fenomena pertanian yang semakin melemahkan posisi petani di tanah air. Diperparah dengan urun rembugnya kebijakan pemerintah yang lebih pro pasar khususnya pasar Internasional daripada pro rakyat kecil dalam hal ini petani. Padahal mereka dalah pahlawan pangan kita, jika mereka sudah tidak mau menanam, maka jangan harap anak cucu kita akan merasakan nasi dari bumi Indonesia.

Jikalahan persawahan semakin berkurang, sementara populasi penduduk Indonesia semakin bertambah, maka otomatis kebutuhan akan pangan semakin bertambah tiap tahunnya, lalu dari mana kebutuhan akan pagan tersebut dapat terpenuhi?maka proyek-proyek impor pangan inilah yang menjadi jalan emas bagi para anggota dewan dalam menekan produk-produk pangan dalam negeri, dengan keuntungan yang melimpah hanya dimakan oleh dirinya sendiri dan sekutunya. Ditambah lagi mental dari bangsa Indonesia yang lebih percaya brand produk dari luar negeri, yang belum tentu kualitasnya lebih baik dari kualitas produksi dalam negeri. Hal ini juga dipicu perdagangan bebas antar negara yang bebas tarif, sehingga semakin memperlancar penggencaran produk-produk luar negeri masuk kedalam negeri. Jika kondisi ini tetap dibiarkan, maka Indonesia akan menjadi sesuai apa yang hanya menjadi pasar-nya negara-negara kapitalis besar, dan menjadi obyek konsumen paling signifikan terlebih jika budaya konsumerisme yang semakin meningkat dari kalangan menengah ke atas. Padahal jika impor semakin banyak tanpa diimbangi oleh ekspor yag banyak pula, maka dalam teori ekonomi adalah akan semakin menekan nilai mata uang dalam negeri, dan otomatis mengurangi pendapatan nasional. Maka sejak kapan impor menjadi trend di Indonesia dan menjadi pilihan utama dalam kebujakan pangan? Maka negara atas nama pemerintahlah yang wajib tanggungjawab atas terlemahkannya petani (produk pertanian) dalam bersaing dengan produk luar negeri dalam pasar negeri sendiri. 
Dari ruwetnya permasalahan di atas, maka sudah selayaknya perekonomian dikembalikan pada apa yang menjadi amanat dari para pendiri bangsa, yakni ekonomi yang berdasar pada nilai 'tolongmenolong' dan berorientasi pada kesejahteraan umum bukan kesejahteraan orang-seorang, yang termaktub dalam dasar negara pancasila yakni 'keadilan sosial bagi seluruh rakyat Indonesia'. Dan secara eksplisit tertulis dalam pasal 33 dan 34 UUD 1945, yang mana bangun usaha yang paling ideal di Indonesia adalah kooperasi, yang mana menjiwai spirit gotong-royong dan kekeluargaan (intinya tolongmenoolong), serta harusnya ksegala aspek kekayaan negara yang menyangkut hajat hidup orang banyak menjadi wewenang dan tanggungjawab negara dalam pengelolaan maupun proteksi atas gangguan dari produk luar.

Maka dalam jelas, dalam rangka melindungi petani supaya terhindar dari pemiskinan sistem dan beralih ke profesi lainnya adalah dengan mendirikan sandaran lembaga untuk mereka dalam rangka menyuplai baik modal, perlengkapan tani, bibit dan pupuk serta obatobatan untuk tanaman maupun tanah, serta suplai tenaga ahli sebagai penyuluh maupun pembina dalam pengembangan usaha pertaniannya (dalam mengelola tanahnya). Maka melalui koperasi usaha tani, hal ini berbeda dari KUD yang pernah digagas di masa Orde Baru (masanya Soeharto). Koperasi ini lebih menjadi wadah khusus tani yang langsung di bawah negara dan mendapatkan proteksi dari nagara, karena di koperasi ini pula didirikan lumbung pangan tempat menyimpan hasil panen saat panen melimpah dan menjadi sumber pangan saat musim paceklik. Namun dalam menjalankan koperasi ini memang dibutuhkan sumber daya insani yang mumpuni baik secara kapabilitas kerjanya (profesional) dan nilai kejujurannya. Karena langsung di bawah negara maka sudah selayaknya petugasnya terakreditasi (mendapat pelatihan dari pemerintah) sehingga mampu menjalankan koperasi secara sitematis dan profesional. Dengan seperti ini diharapkan petani naik derajat, dan memicu generasi muda 
untuk melanjutkan profesi para petani, tentunya dengan pengembangan pada usaha penanamannya melalui sarjana-sarjana petani yang dihasilkan oleh berbagai perguruan tinggi sebagai penyuluh maupun pendampingan bagi petani.

Dari tingkat makro, perlu ada upaya pemerintah dalam memperketat proteksi terhadap petani beserta lahannya melalui konstiusi yang pro dengan petani, sehingga mampu menjadi sandaran bagi petani untuk tetap menjaga profesinya.

\section{e. Merebut masa kesuksesan pertanian}

Setelah melalui perjuangan yang cukup lama dan dengan curahan tenaga, pikiran dan dana yang tidak sedikit, pada tahun 1984 Indonesia untuk pertama kalinya berhasil mencapai swasembada, bahkan surplus pangan beras. Surplus beras tersebut tercermin pada perubahan stok beras yang dikuasai oleh Bulog pada 1984/1985. Pada tahun 1984/1985 jumlah pengadaan beras oleh Bulog di dalam negeri sebanyak 2,382 juta ton setara beras, sedangkan kebutuhan penyalurannya hanya berjumlah 1,612 juta ton beras. Dengan demikian dapat dikatakan bahwa tahun 1984/1985 terdapat surplus beras paling tidak sebanyak 0,770 juta ton setara beras. Keadaan yang serupa juga terjadi pada tahun 1985/1986. Pada tahun etrsebut jumlah pengadaan beras dalam negeri oleh Bulog mencapai 1,953 juta ton, sedangkan kebutuhan penyalurannya hanya 1,549 juta ton. Dengan demikian terdapat surplus sebesar 0,404 juta ton beras. (Arifin, 1994)Prestasi tersebut tidak saja menggembirakan pemerintah dan rakyat Indonesia, tetapi juga dikagumi oleh dunia internasional. Karena Indonesia mampu mengubah posisinya dalam peta pemberasan internasional dari negara pengimpor terbesar menjadi negara yang berswasembada.

Tulisan ini bukan menitikberatkan pada prestasi, namun lebih menitikberatkan pada kemampuan mandiri dan bertahan dalam urusan pangan sehingga mampu memberikan daya tawar bagi negara 
terhadap negara-negara lain, dan khususnya dalam mensejahterakan rakyatnya.

Seperti yang dilakuka oleh Ghazan Khan dan Sultan Alauddin Khaldji, mereka memimpin wilayahnya dari kondisi yang minim dan penuh dengan konflik. Berkat keuletan dan kearifan dalam menata sistem pemerintahan, sehingga saat dan setelah pemerintahan mereka kondisi berbalik dari kondisi ketika awal mereka memimpin wilayahnya. Terobosan dalam membuat kebijakan di dalam pertanian dari ghazan khan dan kebijakan sistem pengaturan harga pasar dari Sultan Alauddin Khadji yang menjadi senjata mereka.

Perpaduan kebijakan dari kedua pemimpin tersebut yang penulis maksud adalah sebagai berikut :

\section{PERPADUAN KEBIJAKAN PANGAN GHAZAN KHAN DAN ALAUDDIN KHILDJI}

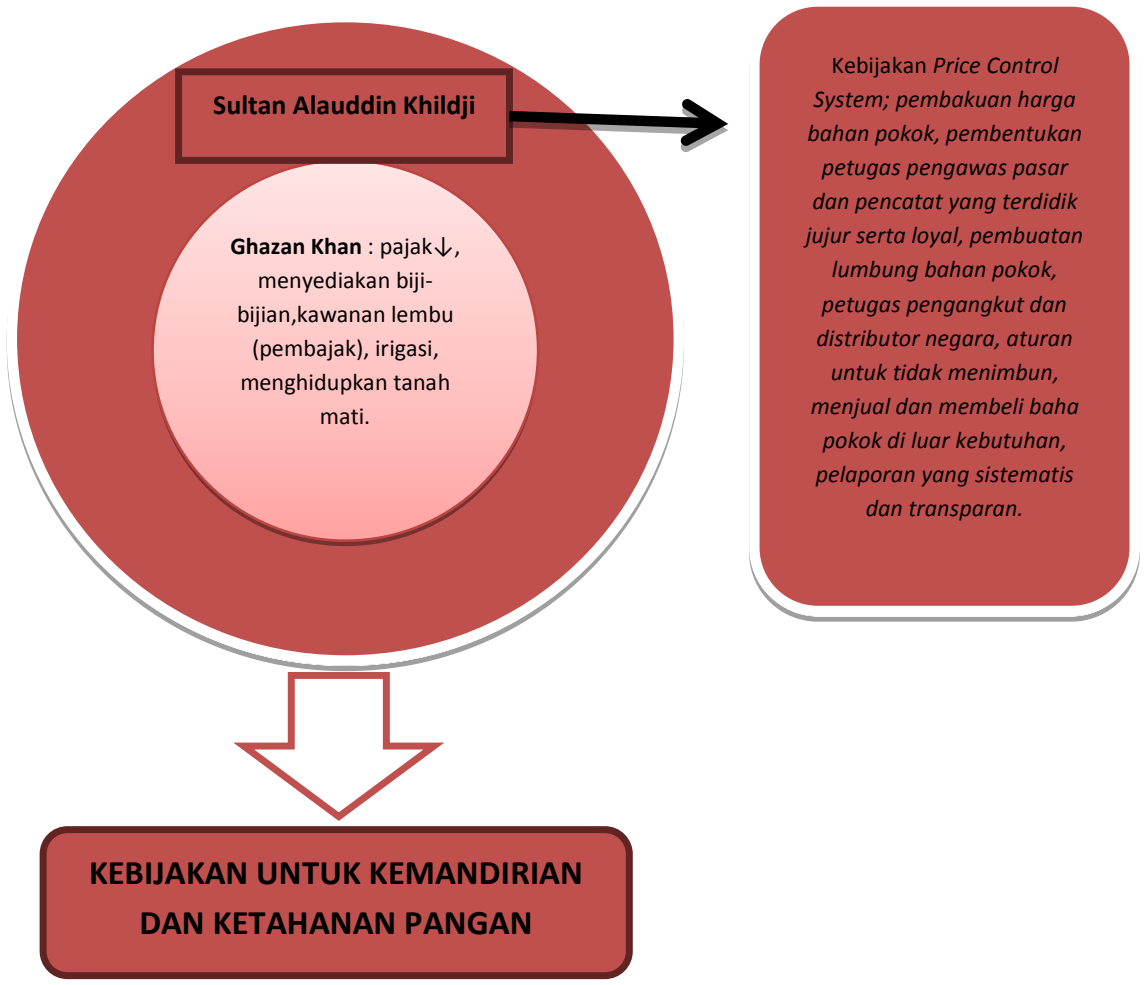

Penjelasan :

Kabijakan Pengendalian harga oleh Sultan Alauddin Khaldji adalah sebagai kebijakan makro untuk stabilitas pasar yang berimbas pada makroekonomi suatu negara dengan beberapa titik tekan di sini adalah 
sistem dan SDM yang ketat dalam hal kejujuran, memfasilitasi operasional lumbung dan distribusi bahan pokok dari tempat produksi (sawah-sawah pelosok daerah) ke pusat perdagangan dan kebijakan pendukung lainnya.

Sementara kebijakan Ghazan Khan fokus dalam internal kebijakan pertanian diantaranya ; penyediaan biji-bijian untuk ditanam, pupuk, irigasi, operasional bajak sawah (kalau masa itu lembu), menghidupkan tanah yang mati (tidak produktif untuk dijadikan lahan pertanian).

Berangkat dari berbagai permasalahan yang disebutkan pada point sebelumnya, kegagalan pemerintahan Indonesia yang mengaburkan kebijakan pertanian dengan adanya wabah industrialisasi, maka kembali fokus pada kebijakan pertanian (agriculture) dalam rangka memperbaiki sistem pangan di Indonesia, maka penulis merasa perpaduan dua kebijakan dari para pemimpin Islam di atas bisa dijadikan solusi.

Hal ini perlu campur tangan pemerintah yang dominan dalam memperbaiki sistem pangandi Indonesia. Dan sebagian besar pemerintah diharapkan bertangan besi dan mampu mencerabut akarakar monopoli yang dilakukan oleh pihak-pihak swastayang kurang berpihak terhadap masyarakat Indonesia. Dari situ pemerintah beralih peran menjadi pengatur utama dalam kebijakan pertanian.

Indonesia merupakan negara agraris dengan bonus demografi yang melimpah (musim, kondisi tanah, tipologi manusia Indonesia dan budayanga, dll). Hanya saja bonus demografi ini belum dimanfaatkan secara optimal. Dengan mengadopsi kebijakan dari Ghazan Khan dan Sultan Alauddin Khaldji, pemerintah dapat melakukan hal-hal sebagai berikut :

- Rekonstruksi kebijakan Produksi Pertanian ; memberikan pasokan baku harga pupuk, bibit, biji-bijian dan bahan-bahan input pertanian dari pemerintah, membuat sarana dan prasarana pertanian misal 
irigasi, lumbung padi dan hasil produksi sawah, pengangkut, dan tekonologi pertanian yang ramah lingkungan.

- Rekonstruksi kebijakan Distribusi dan Pasar pangan ; dengan membuat standart harga-harga bahan pokok setara dengan kemampuan daya beli masyarakat Indonesia termiskin, konektivitas antara harga hasil panen dari sawah dan di pasar tidak menonjol, distributor yang dikoordinir langsung oleh pemerintah dalam rangka memotong mata rantai tengkulak yang merugikan petani dan konsumen pangan, Penentuan harga pasar di luar bahan pokok ditentukan oleh pasar dengan beberapa batasan maksimal dan minimal harga yang ditentukan oleh pemerintah.

- Rekonstruksi pembinaan SDM melalui juklak (petunjuk pelaksana); Selain mentality dan commitmentyang ditekankan, ada aturan jelas terkait tupoksi dari masing-masing pihak yang terkait dalam kebijakan pangan misal terkait petani (saat mengelola tanah dan tanamannya), distributor, dan penjual maupun pembeli di pasar), adanya aturan jelas terkait pihak-pihak pengawas dan petugas khusus dari pemerintah yang menjadi agen pembantu dalam sirkulasi kebijakan pangan yang dibawahi langsung oleh lembaga pemerintah.

- Adanya lembaga keuangan bank (LKB) mikro yang konsisten menjadii rumah pembiayaan bagi petani dalam menjalankan usaha pertaniannya. Maupun untuk pedagang bahan-bahan pangan sebagai motor distributor dalam menjalankan fungsinya sebagai mediator keuangan sehinggga dapat membenihkan usaha-usaha produktif dari petani maupun pihak lain dalam sirkulasi kebijakan pangan. Kalau dulu KUD, maka hari ini bisa saja melalui koperasi komunitas petani di suatu desa dan atau lembaga keuangan mikro lain yang ada di suatu tempat dengan tanpa hanya meninggalkan para petani dalam pelayanan jasa keuangannya. LKB mikro di sini selain menjadi sarana penyuluh dana juga bisa sebagai sarana 
penyuluh ilmu dan informasi untuk menjadi lebih produktif dalam usaha tani dan lainnya.

- Terkait perkembangan pasar bebas antar negara hari ini, maka kebijakan ini dipakai sebagai affirmative action dalam memproteksi produki pangan dalam negeri agar tidak dicampuri oleh kekuatan asing selama ketahanan dan kemandirianpangan di Indonesia belum bisa diwujudkan. Daya tawar ini perlu dilakukan oleh pemerintah sebagai bentuk upaya melindungai segenap tumpah darah Indonesia yang ada di negeri Indonesia.

\section{Kesimpulan}

Berbasis pelajaran sejarah dari dua tokoh Islam di India dan Persia (Sultan Alauddin Khaldji dan Ghazan Khan) bagi penulis layak dijadikan referensi dalam upaya rekonstruksi kebijakan pangan di Indonesia dengan berangkat dari latar yang sama (kocar-kacirnya kondisi perekonomian terutama sistem pangan, mayoritas penduduk Muslim dan pemerintah yang seharusnya bisa menjadi pemain utama sebagai protektor dalam sistem kebijakan pangan), maka mengadopsi dan memodifikasi kebijakan pangan dari kedua tokoh tersebut (dengan tanpa meninggalkan latar historis dan budaya Indonesia) layak menjadi referensi dalam membenahi politik pangan menuju ketahanan pangan di negeri yang kaya SDA nan subur ini. Maka beberapa rekonstruksi aspek dalam menunjang ketahanan pangan di antaranya rekonstruksi sistem produksi, distribusi dan pasar pangan. Ditambah dengan rekonstruksi kebijakan SDM sebagai pelaku-pelaku utama sebagai implementor dalam kebijakan pangan dan didukung oleh daya serap dan supply dana dalam kataliasator operasionalisasi pertanian dan pasar pangan di wilayah tertentu.

\section{Daftar Pustaka}

Noufal F, Zacky, Petaka Politik Pangan Indonesia : Konfigurasi Kebijakan Pangan yang Tak Memihak Rakyat, (Malang : Intrans Publishing, 2010), hal 1-2. 
Arin Setiyowati_Politik Pangan: Konstruksi Kebijakan Dalam Rangka Konsolidasi Ketahanan Ekonomi Indonesia (Tinjauan Sosio-Historis Kultural Ekonomi Islam)

Arifin, Bustanil, Pangan dalam Orde Baru, Jakarta : Koperasi Jasa Informasi (KOPINFO), Cet Kedua 1994, hal 244-245.

Dudung, Siti Maryam dkk, Sejarah Peradaban Islam ; dari masa Klasik hingga modern, cet 2 (Yogyakarta : LESFI, 2004).

Elliot, H.M., The History of India as Told by its own Historians, (London : Turbner \& Co, 1869) III.

Niazi, Ghulam Sharwar Khan, The Life and Workers of Sultan Alauddin Khalji, (New Delhi : atlantic Publishers \& Distributor, 1992).

Thohir, Ajid, Perkembangan Peradaban di Kawasan Dunia Islam, (Jakarta : Raja Grafindo Persada, 2004).

Ali, K., History of India Pakista and Bangladesh, (Dacca : Ali Publisher, 1980).

Karim, M. Abdul, Sejarah Islam di India, (Yogyakarta : Bunga Grafis Production, 2003).

Sejarah Pemikiran dan Peradaban Islam,

(Yogyakarta : Pustaka Book Publisher, 2012).

Rianto, Al Arif M Nur dkk, 2010, Teori Mikroekonomi : Suatu perbandingan Ekonomi Islam dan Ekonomi Konvensional, Jakarta : Kencana.

Hitti, Phillp K., 2008, History of The Arabs : From The Earliest Times to The Present (Terjemahan), Jakarta : PT Serambi Ilmu Semesta.

Lapidus, Ira M., Sejarah Sosial Ummat Islam Bagian Kesatu \& Kedua, (Jakarta : PT RajaGrafindo Persada, 1999)

Rosidah, Dede. Kebijakan Ekonomi Ghazan Khan Pada Masa Dinasti Ilkhan diPersia. Yogyakarta: Skripsi. 2012.

Lambton, Ann K. S. Continuity and Change in Medieval Persia: Aspects of Administrative, Economic, and Social History 11 th-14 th Century. London: I. B Taurist and co. Ltd, 1988.

Lambton, Ann K. S. Landrold and Peasant in Persia: A Study of Land Tenure and Land Revenue Administration. Oxford: University Press, 1969. 